\title{
Do investors in Spain react to news on sustainability and corporate social responsibility?
}

\author{
M.A. Fernandez-Izquierdo*, \\ V.A. Arago-Manzana, J.C. Matallín-Sáez \\ and L. Nieto-Soria
}

Department of Finance and Accounting, Universitat Jaume I, Castellón, Spain

E-mail: afernand@cofin.uji.es

E-mail: arago@cofin.uji.es

E-mail: matallin@cofin.uji.es

E-mail: nieto@cofin.uji.es

*Corresponding author

\begin{abstract}
We analyse whether sustainability and corporate social responsibility-related news affects returns of stocks traded on the Spanish stock market. We used event methodology and an approach consistent with the active management of investment portfolios. Results show that in the short term, investors do not consider these news items to be relevant, and they therefore have no effect on the price of the stocks analysed. This result holds when the study is conditioned to the type of news (positive or negative) and whether or not the stocks belong to an index formed following socially responsible investment criteria.
\end{abstract}

Keywords: corporate social responsibility; investment; news; sustainability.

Reference to this paper should be made as follows: Fernandez-Izquierdo, M.A., Arago-Manzana, V.A., Matallín-Sáez, J.C. and Nieto-Soria, L. (2009) 'Do investors in Spain react to news on sustainability and corporate social responsibility?', Int. J. Sustainable Economy, Vol. 1, No. 3, pp.227-244.

Biographical notes: María Ángeles Fernández-Izquierdo is a PhD in Financial Economics and Accountancy at the Universidad de Valencia. She is currently a full professor in Financial Economics at the University Jaume I in the Castellón University, Spain. Prior to taking this position, she worked as an Economist in the Valencia Stock Exchange.

V.A. Arago-Manzana is a graduate in Business Administration at the University of Valencia and a PhD in Financial Economics University Jaume I. $\mathrm{He}$ is currently a Professor of Finance at University Jaume I in Castellón, Spain. He was a visiting researcher at the University of Valencia, University Carlos III of Madrid and Public University of Pamplona.

Juan C. Matallín-Sáez is a graduate in Business Administration at the University of Valencia and a PhD in Financial Economics at the University Jaume I. He is currently a Professor of Finance at the University Jaume I. Prior to taking this position, he has worked as a consultant in the Internet industry. $\mathrm{He}$ was a visiting researcher at the University of Valencia and University Carlos III of Madrid.

Copyright (C) 2009 Inderscience Enterprises Ltd. 
Luisa Nieto-Soria is a PhD in Business Administration at Universitat Jaume I in Castellón, Spain. She is currently a Professor of Finance at the Financial Economics and Accounting Department of the University Jaume I in Castellón, Spain. He was a visiting researcher at the Griffith University (Brisbane, Australia).

\section{Introduction}

The aim of this study is to analyse whether news related to any area of sustainability and corporate social responsibility (CSR) affects companies' financial returns in the short term. We are particularly interested in investigating the extent to which the preferences of investors operating in the market may be determinant in the Spanish case.

Analyses of this issue are highly pertinent today due to the growing interest in the stream of economic thought advocating social responsibility on the part of companies, and in light of the considerable increase in the volume of resources companies invest to meet sustainability and CSR criteria. A similar phenomenon has occurred in Spain; listed companies are more likely to produce information for interested parties, but the degree to which sustainability and CSR has been introduced falls below international levels (Deloitte and Esade, 2004)

The application of sustainability and CSR policies has led to debate on the repercussions of these dimensions have for company owners. The socio-economic model perspective (Carroll, 1979; Freeman, 1984) contends that firms have responsibilities that go beyond the maximisation of profits for their shareholders, and claims that if firms consider (ignore) the needs of the various interest groups, their stakeholders, a positive (negative) effect will be seen on their results and on shareholders' profits. Social and economic aspects are therefore inseparable and at the same time, help to improve firms' competitiveness (Drucker, 1984; Porter and Kramer, 2002).

However, where sustainability and CSR is truly gaining ground in the context of short term business activity is in the financial markets, with the development of socially responsible investments (SRIs) and funds, the creation of control bodies and a range of sustainability and CSR ratings, the spread of awareness in all business spheres, etc.

There is an extensive empirical literature on the growth of awareness in financial markets about the incorporation of sustainability and CSR policies by firms. These studies are not easily classified, as in many cases they cover more than one aspect. Nonetheless, in an attempt to describe the current situation, we will classify the research into two main blocks. The first block analyses the relationship between sustainability and CSR and stock prices. While the analysis is not conclusive, the idea seems to be generally accepted that when responsible conducts are introduced into the management and administration of stocks, they take on added value (Waddock and Graves, 1997). Thus, Simpson and Kohers (2002) demonstrate a positive relationship between the two, and Barnett and Salomon (2006) provide evidence that the relationship is not linear, but curvilinear.

The second block of empirical research analyses whether sustainable and SRI implies any sacrifice in terms of returns for investors. These studies carry out comparative analyses of returns on ethical investments with those of conventional investments, either by using ethical stock indexes vs. conventional stock indexes, as in the study by Vermeir 
and Corten (2001); socially responsible mutual funds vs. classic mutual funds, as in the work of Statman (2000), Kreander et al. (2005) and Bauer et al. (2007) or by comparing returns of SRI stocks with non-SRI stocks as in Stone et al. (2001), Hill et al. (2003) or Shank et al. (2005). Most of these studies report no significant differences between ethical and non-ethical investment returns.

Traditionally, event study methodology has been used to estimate whether the impact of news can generate an abnormal daily return. As a first step, our research uses a nonparametric test in order to test the null hypothesis of zero abnormal returns. We propose a second step to contrast the information contents of these news items by means of an alternative methodology based on active portfolio management. Our study differs from other analyses by the effect of sustainability and CSR news on stock prices in several ways:

1 It examines all areas of sustainability and CSR and is not restricted to single issues such as environment or corporate governance.

2 The study is first performed on the complete set of news items and is subsequently conditioned to the sign of the news item (positive or negative).

3 It attempts to analyse whether differences exist between stocks included in sustainable indexes and those that are not.

4 The analysis takes a dual approach: on one hand, we study whether the market reaction to the arrival of sustainability and CSR-related news can generate significant abnormal returns in the stocks of companies affected by the news, and on the other, we study whether an actively managed portfolio taking decisions to buy (sell) based on the arrival of positive (negative) sustainability and CSR-related news is capable of bettering the result of a portfolio made up of the same stocks, but that follows a buy-and-hold strategy.

The main conclusions of our study show no evidence of abnormal return behaviour of the stocks analysed around the date the sustainability and CSR news was announced. This finding holds when we consider both the sign of the news and whether or not the company is included in an SRI index. Indeed, our results reveal no short-term reactions reflected in stock price variations during the period analysed and in the companies considered. We also demonstrate that an actively managed portfolio following criteria to buy and sell based on sustainability and CSR-related news does not obtain higher returns than those it would obtain according to the systematic risk it bears. This result is only applicable to short-term investment strategies and in no case may be taken to indicate that socially responsible behaviour does not have beneficial effects, for example, on the company's image and reputation, which may have a greater influence on this return in the long term (see e.g. Waddock and Graves, 1997).

The rest of the paper is organised as follows. The second section provides a review of the literature. Section 3 gives an overview of the importance of sustainability and CSR and SRI in Spain. The methodology and database used in the empirical study are outlined in Section 4. This section also introduces the hypotheses that we test empirically in the study. Section 5 presents the results and thus ends with a summary of our main conclusions and the bibliography. 


\section{Literature review}

The academic field holds two opposing views on the issue. The stakeholder theory (Freeman, 1984) argue that shareholders are just one of the multiple stakeholder groups managers must consider in their decision-making process. Stakeholder groups include internal, external and environmental elements. Like shareholders, other stakeholders may place demands upon the firm, thus conferring it social legitimacy. Firms must address these demands or else face negative confrontations from non-shareholder groups, which can lead to diminished shareholder value through boycotts, lawsuits, protests, etc. (Ruf et al., 2001). Critics of stakeholder theory refer to Friedman (1970) to defend the argument that the attention managers pay to interests other than those of their investors give rise to a loss of investor confidence and thus a decrease in investor welfare.

Attempts to find evidence that would support or refute these theories soon began to appear, and ever since Moscowitz (1972) put forward the idea that a portfolio made up of socially responsible assets performed equally or better than a portfolio whose assets lacked these characteristics, a large number of studies have analysed the relationship between sustainability and CSR and financial performance.

However, it is on the corporate financial market scene that the sustainability and CSR philosophy is gaining ground with the development of funds managed according to what is known as SRI, the creation of auditing institutions, various CSR and SRI index ratings, the spread of awareness at all corporate levels, etc. Awareness of the relationship between a company's social and financial performance has grown on the financial stock markets. The issue has been empirically analysed and the outcomes can be grouped into two main blocks:

1 The impact that sustainability and CSR-related news may have on the stock market price and therefore on the stock market value.

2 Empirical research that attempts to analyse whether SRI by mutual funds implies a sacrifice or a reward for the investor.

\subsection{Sustainablity and stock prices}

Empirical research into stock price reaction to sustainability and CSR-related news focuses on whether abnormal returns exist around the day the news was first made public in order to determine to what extent investors react to corporate socially responsible/irresponsible actions. Most of these analyses use event study methodology to assess the impact the news items have on stock returns. They implicitly assume that the arrival of new information to the market influences the stock returns and gives rise to an abnormal return with a sign that reflects investors' sensitivity to the news.

Margolis and Walsh (2001) review 122 studies that empirically analyse this relationship, concluding that empirical results are mixed. One reason could be the differences in the methodologies and the variables used in these studies, i.e. the nature of the announcement, the size of the companies or the specific social aspect they set out to analyse. Among the most recent contributions, Tsoutsoura (2004) evaluates firms included simultaneously in the S\&P 500, the Kinder Lydenberg Domini rating and the Domini 400, using risk, size and industrial sector as control variables and finds a positive association between sustainability and CSR and financial performance. McWilliams et al. (1999) carry out an analysis of event study methodology used in previous studies into the 
impact of CSR news. In addition to provide a wide range of literature classified according to topic, field, event and author, they conclude that the CSR actions they examined have no financial significance.

\subsection{Financial return and SRI}

A second stream of empirical studies analyses the performance of a portfolio of socially responsible corporations, or in other words, SRI and compares it to the performance of a benchmark (such as market indexes or non-SRI portfolios). This group comprises both research into retail SRI funds and that of ad hoc portfolios that might be considered as SRI. In the opinion of Mill (2006), this second possibility has the advantage of allowing to control for performance effects to 'coincidental' concentration in investment sectors that are doing well or badly over a given period of time.

Of the papers that analyse the financial performance of retail SRI funds, the studies by Statman (2000) on US funds or Kreander et al. (2005) whom use a matching approach, are particularly relevant. Recent studies, such as Mill (2006), examine the financial performance of a unit trust that was initially conventional and later adopted the SRI principle, finding that performance remained unchanged by the switch to SRI; Bauer et al. (2007) on Canadian mutual funds support the assumption that any performance differential between ethical mutual funds and their conventional peers is statistically insignificant. In the Spanish market, Fernández-Izquierdo and Matallín-Sáez (2007) find that the financial performance of SRI funds is in all cases superior or similar to that obtained by the other funds. The review of the literature on SRI fund performance shows that their performance is similar to that of conventional funds. This result is well founded as the research makes use of different methodologies, time periods and countries.

Of the comparative studies that deal with SRI and non-SRI stock portfolios, Diltz (1995) finds no statistically significant differences; Kurtz and Dibartolomeo (1996) report 19 basis points of monthly outperformance of the Domini social index (DSI) relative to the S\&P 500, which they attribute to the higher price volatility and higher price-to-book ratios of the DSI stocks. Guerard (1997) uses an objectively specific return forecasting model to compare the performance of two actively managed portfolios - one with SRI stocks, and the other with non-SRI stocks - to conclude that SRI companies bear no additional management costs. However, he does not find sufficient evidence to accept that these companies are better managed. Stone et al. (2001) extend Guerard's paper by using a mathematical assignment program to form a portfolio match and discover that portfolios with SRI stocks do not display worser performance than non-SRI stocks.

\subsection{Sustainability and CSR and SRI in Spain}

The beginnings of SRI in Spain can be dated to 1997 with the appearance of the first 'green fund' on the retail market. However, it was not until 1999-2000 that the market acquired any real importance. This year saw the introduction of SRI mutual fund regulation with the "Circular on the use of collective investment under the denomination of ethical, environmental or any other term with a bearing on aspects of social responsibly" issued by Ethics Committee of the Spanish Association of Fund Managers (Inverco). Lozano et al. (2006) provide evidence of certain dynamism in the development of SRI funds in the Spanish retail market, but if we compare it with the development of other similar SRI retail markets, we see that the Spanish market is relatively underdeveloped. 
Table 1 Ibex 35 stocks that belong to an SRI index

\begin{tabular}{lccc}
\hline Ibex 35 stocks & FTSE4Good & Dow Jones sustainability & Ethibel sustainability index \\
\hline BBVA & $\mathrm{X}$ & & \\
SCH & $\mathrm{X}$ & $\mathrm{X}$ & \\
Inditex & $\mathrm{X}$ & $\mathrm{X}$ & \\
Telefónica & $\mathrm{X}$ & $\mathrm{X}$ & $\mathrm{X}$ \\
Gas natural & $\mathrm{X}$ & & \\
Bankinter & $\mathrm{X}$ & $\mathrm{X}$ & \\
Iberdrola & & $\mathrm{X}$ & \\
Endesa & & $\mathrm{X}$ & $\mathrm{X}$ \\
Ferrovial & & $\mathrm{X}$ & $\mathrm{X}$ \\
Amadeus & & & \\
Agbar & & & \\
\hline
\end{tabular}

More recently, the unified code of good governance for listed companies appeared in 2006. This code, known as the Conthe code, includes some of the recommendations from the previous reports (Olivencia, 1998; Aldama, 2003) and incorporates further recommendations from the European Commission and credit entities approved by the Basel committee on banking supervision, as well as the up-dated version of the OECD Corporate Governance principles. From 1997 to 2002, a period in which the application of all aspects of CSR was voluntary, some firms listed in the Spanish stock exchange showed their willingness to form part of ethical stock indexes drawn up by ratings companies and ethical mutual fund portafolio. In addition, as analysed by Muñoz et al. (2004), most Spanish SRI funds invest in Spanish equities only if they belong to one of the ethical indexes. Table 1 lists the companies and the SRI indexes they belong to.

\subsection{Database and methodology}

In order to analyse whether news related to any area of sustainability and CSR has an effect on the firm's short-term financial return, we use three types of data: data on firms, data on stock prices and data on sustainability and CSR-related news.

Two criteria were taken into account when selecting the companies for this study: firstly, they must have been listed in the Ibex 35 during the period analysed, which guarantees that they have a large turnover, high liquidity and sufficient following by investors and the press. The final sample did not include all the Ibex 35 listed companies because some of them had either no sustainability and CSR-related news or too many news items in a short period of time ${ }^{1}$; the study finally analysed a total of 11 firms. They were split into two groups, one for companies that belong to an SRI index (SRI stocks: Aguas de Barcelona (Agbar), Iberdrola, Ferrovial, Telefonica, Endesa, Inditex and Gas natural; these represent $39 \%$ of the Ibex 35 capitalisation) and a second group of companies that do not belong to any SRI index (non-SRI stocks: ACS, Altadis, SacyrVallehermoso, Repsol, Unión Fenosa; these represent 13\% of the Ibex 35 capitalisation). 
By isolating the effect that inclusion in an SRI index may have, the comparison of the results obtained for each sample group assured robustness of the empirical analysis.

Stock prices were taken from the Intertell database, which is adjusted for capital increases, dividend payments and other special operations that might affect stock prices. In order to determine whether a particular news item could be classified as an action of CSR the news studied was related to: business conduct, community involvement, corporate governance, environment, attitudes towards consumers and the market and the workplace. We collected news items on sustainability and CSR that appeared in the newspapers during the period October 1997 to December 2002. In Table 2 we show the news classification by sustainability and CSR items. Of a total of 156 news items, 54 were related to the environment, 26 to labour relations and 24 to competition.

Classification of the news items as positive (or negative) was made by considering them to be positive (negative) when they contained information that showed the company operating in harmony (in conflict) with the economic, social and environmental context deriving from the sustainability and CSR concept, in conjunction with the consensus reached by the research group. Thus, we defined as positive (negative) news that covered a fact or activity referring to a specific company and with possible favourable (unfavourable) impacts on its stakeholders. Under this criterion, we classified 83 news items as positive and 73 as negative. The topic with the highest number of positive classifications was the environment (39), while the highest number of negative classifications referred to competition (20).

We also eliminated announcements from the sample that, in the time period covered by the research, coincided with other news unrelated to sustainability and CSR that might have had an influence on the results of the company in question to eliminate the 'confounding effects' (McWilliams and Siegel, 1997). The final sample comprises 75 SRI-stock-related and 81 non-SRI-stock-related announcements as shown in Tables 3 and 4 classified by firm. The distribution of positive and negative announcements between the SRI and non-SRI groups of companies is not homogenous. The SRI companies have a higher number of positive news items (46), while the non-SRI companies have more negative news items (44).

Table 2 News classification by sustainability and CSR topic

\begin{tabular}{lccc}
\hline & Positive & Negative & Total \\
\hline Business conduct & 4 & 20 & 24 \\
Community & 9 & 1 & 10 \\
Consumers & 3 & 9 & 12 \\
Corporate governance & 10 & 5 & 15 \\
Workplace & 10 & 16 & 26 \\
Environment & 39 & 15 & 54 \\
Other & 8 & 7 & 15 \\
Total & 83 & 73 & 156 \\
\hline
\end{tabular}


Table 3 Data base CSR news classified by firm (SRI stocks)

\begin{tabular}{|c|c|c|c|}
\hline \multirow[b]{2}{*}{ SRI Ibex 35 stocks } & \multicolumn{2}{|c|}{ Number of news items } & \multirow[b]{2}{*}{ Sector main activity } \\
\hline & Positive & Negative & \\
\hline Agbar & 5 & - & Water \\
\hline Iberdrola & 10 & 5 & Electricity \\
\hline Ferrovial & 3 & 2 & Building \\
\hline Telefónica & 8 & 11 & Telecommunication \\
\hline Endesa & 7 & 10 & Electricity \\
\hline Inditex & 5 & 1 & Textile \\
\hline Gas natural & 8 & - & Gas \\
\hline Total & 46 & 29 & \\
\hline
\end{tabular}

Table 4 CSR news database classified by firm (non-SRI stocks)

\begin{tabular}{lccl}
\hline & \multicolumn{2}{c}{ Number of news items } & \\
\cline { 2 - 4 } Non-SRI Ibex 35 stocks & Positive & Negative & Sector main activity \\
\hline ACS & 12 & 8 & Building \\
Altadis & 5 & 12 & Tabacco \\
Sacyr-, Vallehermoso & 8 & 1 & Building \\
Repsol & 6 & 16 & Oil \\
Unión Fenosa & 6 & 7 & Electricity \\
Total & 37 & 44 & \\
\hline
\end{tabular}

\section{Methodology}

\subsection{Event study methodology}

Since Fama et al. (1969) event methodology has been extended to the fields of finanace. This methodology allows us to analyse the reaction of stock prices as a result of the arrival of news to the market. In other words, it enables us to test whether investors attach any value to the information content of a news item.

When the information contained in a news item is relevant to the market, investors will interpret the influence of the information on each specific stock and modify their investment strategy accordingly. The stock price will vary as a result of this position, and this variation will give rise to the existence of abnormal returns. If, on the other hand, investors do not consider the information to be of any use, they will not react to the news and the stock return will be the same as might have been expected in the absence of new information.

This research uses the returns on the stocks selected for study as the dependent variable, and sustainability and CSR news as the independent variable. As indicated above, our objective is to analyse whether these announcements have any influence on stock returns. The return is calculated as the logarithm of the ratio between two consecutive daily prices. 
Two stages can be clearly identified in the application of this methodology. The first stage estimates the abnormal returns generated by the arrival of information to the market and the second stage tests whether these abnormal returns are statistically significant. Abnormal returns are estimated using the market model, the return of each stock $\left(r_{i t}\right)$ is obtained from expression (1)

$$
r_{i t}=\alpha_{i}+\beta_{i} r_{m t}+\varepsilon_{i t} \quad i=1,2, \ldots, N \quad t=T_{1}, \ldots, T_{n}
$$

Where $r_{i t}$ and $r_{m t}$ are, respectively, the observed returns of each stock and of the market portfolio, $N$ is the number of stocks included in the sample and $n$ the number of periods. In our case $n$ is 30 trading days and the model is estimated by ordinary least squares (OLS) for each stock and each news item. Thus the estimators of the coefficients are then used to calculate daily abnormal returns for each day within the event window. In order to study the aggregate effect of the event by the end of a particular period $\left(t_{1}, t_{2}\right)$ cumulative abnormal returns (CAR) must be calculated.

As mentioned above, once the CAR resulting from the events have been estimated, the second stage is to test whether they are statistically different from zero.

We use non-parametric test by Corrado (1989), because this test does not assume any hypothesis about the distribution of returns. The Corrado test is based on the rank of abnormal return on event day with respect to an interval including pre-event and event days. A further attractive feature of this non-parametric test is that it is relatively robust to variance increase on the event date.

Let moment $T=0$ be the day when an item of news related to a stock is published in the press. In this paper, we use a maximum of 41 days around the publication of the news to analyse its effect. The first 30 days (from $T_{0}=-35$ to $T_{n}=-6$ ) represent the estimation window, while the remaining 11 days $\left(T_{1}=-5\right.$ to $\left.T_{2}=+5\right)$ cover the event window.

We considered a variety of window ranges, specifically: $11(-5,+5), 9(-4,+4), 7$ $(-3,+3)$ days. The pre-event window $(-5,-1)$ allows us to capture any possible market anticipations of news publication. In this way, we are able to take into account the possibility of any leakage of information prior to the publication of the news in the press. Moreover, the post-event date side of the window $(+1,+5)$ enables us to analyse the gradual market reaction to the publication of the news.

\subsection{Calendar-time portfolio approach}

Two actively managed portfolios were created, incorporating decisions to buy or sell stocks according to the positive or negative sign of the news for the firm from a sustainability and CSR point of view. Both portfolios were subject to the convexity condition, i.e. the weights of the stocks that form the portfolio sum to unity. An observation period made up of the five daily returns before and after the event date was maintained around the event dates. Despite their different constructions, both portfolios had common modifications on an equally weighted portfolio investing in the stocks under study. The first portfolio created did not allow the existence of short positions on stocks. In the second portfolio, short positions on stocks were allowed. 
The performance of portfolios was then analysed. If sustainability and CSR news had a positive effect on the stock price during the observation window, it was expected that these portfolios would exhibit a positive performance, since the active management incorporated into the portfolios involved an increase (decrease) in the stock weights in the case of positive (negative) news. Although there is a wide typology of performance measures available when returns are used as the information to be measured, in this study we apply two of the most widely used measures, namely Sharpe (1966) and Jensen (1968).

Firstly, the Sharpe index $\left(\mathrm{IS}_{p}\right)$ in Equation (2) adjusts $E\left[r_{p}\right]$, the mean return of the portfolio $p$ in excess of the risk-free asset, to its total risk, measured by the standard deviation $\sigma_{p}$.

$$
\mathrm{IS}_{p}=\frac{E\left[r_{p}\right]}{\sigma_{p}}
$$

Secondly, the portfolio mean excess return is adjusted to a systematic risk factor using model (3) (Jensen, 1968). From the Sharpe (1992) approach, model (3) can be seen as a comparison between the results obtained by actively managed portfolio $p$ and those obtained by a benchmark $B$ (the latter by definition implies a passive management strategy). The constant of the model, $\alpha_{p}$, assesses the active management of a portfolio in such a way that a positive, significantly different from zero value expresses good performance.

$$
r_{p t}=\alpha_{p}+\beta_{p B} r_{B t}+\varepsilon_{p t}
$$

Several benchmarks are used to measure performance. In the first place, a market index was created as a general proxy of the stock market. However, we found evidence that the good performance of portfolios was due to the performance in their stock per se and not to the effect that news items had on them. As Sharpe (1992), Elton et al. (1993) and Pástor and Stambaugh (2002) point out, even when the return has been adjusted to risk, we may still find evidence of biased performance if we do not take into consideration the characteristics of the assessed portfolio itself. Therefore, to avoid this bias, an equally weighted portfolio that invests in the stocks analysed is used as a control portfolio. In this way, performance evaluates the differences between the control portfolio and the portfolios that are exclusively associated to the active management which changes the stock weights based on the sign of the sustainability and CSR news.

In addition, the results might be spuriously obtained by a simple random distribution within the observation windows associated to the event days. For these reasons, a robustness study was performed using simulation. This analysis consisted of generating random portfolios to be used as benchmarks. These portfolios followed the same active management strategy, but with randomly distributed observation windows, and therefore it did not expressly gather the effect of sustainability and CSR news. This procedure was repeated 10,000 times, obtaining a simulated portfolio each time. The same method was also applied to the portfolio without short positions restrictions. 


\section{Results}

\subsection{Event study}

Tables 5 and 6 present the results from the Corrado (1989) non-parametric rank test for SRI stocks and non-SRI, respectively, for the $(-3,+3)$ event window ${ }^{2}$, where 0 is the day on which the news was published. This is used to test whether the CAR are statistically different from zero. The column on the left shows the CAR, the Corrado statistic and its $p$-value for all the sustainability and CSR news items; the central column shows the CAR, the Corrado statistic and its $p$-value for all the positive news items and the column on the right shows the CAR, the Corrado statistic and its $p$-value for all the negative news items.

Table 5 Results of Corrado test for SRI stocks

\begin{tabular}{|c|c|c|c|c|c|c|c|c|c|}
\hline & \multicolumn{3}{|c|}{ All news } & \multicolumn{3}{|c|}{ Positive news } & \multicolumn{3}{|c|}{ Negative news } \\
\hline & CAR (\%) & Statistic & $\overline{p \text {-value }}$ & CAR (\%) & Statistic & $\overline{p \text {-value }}$ & CAR (\%) & Statistic & p-value \\
\hline-3 & 0.23 & 0.02 & 0.98 & 0.20 & 0.02 & 0.99 & 0.85 & 0.06 & 0.95 \\
\hline-2 & 0.24 & 0.01 & 0.99 & -0.01 & 0.00 & 1.00 & 1.31 & 0.07 & 0.94 \\
\hline-1 & 0.56 & 0.02 & 0.99 & 0.13 & 0.00 & 1.00 & 1.44 & 0.08 & 0.93 \\
\hline 0 & 0.32 & 0.02 & 0.99 & -0.55 & 0.01 & 0.99 & 1.82 & 0.08 & 0.94 \\
\hline 1 & 0.36 & 0.02 & 0.98 & -0.64 & 0.01 & 0.99 & 1.84 & 0.09 & 0.93 \\
\hline 2 & 0.24 & 0.03 & 0.98 & -0.76 & 0.02 & 0.99 & 1.95 & 0.11 & 0.92 \\
\hline 3 & 0.37 & 0.03 & 0.97 & -0.86 & 0.03 & 0.98 & 2.36 & 0.11 & 0.91 \\
\hline
\end{tabular}

Note: this table shows the results of the Corrado non-parametric test performed for the SRI stocks. The column on the left shows results for all the CSR news items; the central column shows results for all the positive news items and the column on the right shows results for all the negative news items. 0 is the day on which the news was published.

Table 6 Results of Corrado test for non-SRI stocks

\begin{tabular}{|c|c|c|c|c|c|c|c|c|c|}
\hline \multirow[b]{2}{*}{ Panel $A$} & \multicolumn{3}{|c|}{ All events } & \multicolumn{3}{|c|}{ Positive events } & \multicolumn{3}{|c|}{ Negative events } \\
\hline & CAR (\%) & Statistic & p-value & CAR (\%) & Statistic & p-value & CAR (\%) & Statistic & $p$-value \\
\hline-3 & -0.06 & 0.01 & 1.00 & -0.28 & 0.00 & 1.00 & 0.13 & 0.02 & 0.98 \\
\hline-2 & -0.16 & 0.01 & 0.99 & -0.19 & 0.01 & 0.99 & -0.14 & 0.03 & 0.98 \\
\hline-1 & 0.05 & 0.02 & 0.99 & -0.06 & 0.02 & 0.98 & 0.14 & 0.03 & 0.97 \\
\hline 0 & 0.07 & 0.02 & 0.99 & 0.02 & 0.03 & 0.98 & 0.11 & 0.04 & 0.97 \\
\hline 1 & -0.17 & 0.02 & 0.98 & -0.20 & 0.03 & 0.97 & -0.14 & 0.04 & 0.97 \\
\hline 2 & 0.18 & 0.03 & 0.98 & 0.21 & 0.05 & 0.96 & 0.16 & 0.05 & 0.96 \\
\hline 3 & 0.09 & 0.03 & 0.98 & 0.22 & 0.06 & 0.96 & -0.02 & 0.05 & 0.96 \\
\hline
\end{tabular}

Note: this table shows the results of the Corrado non-parametric test performed for the SRI stocks. The column on the left shows results for all the CSR news items; the central column shows results for all the positive news items and the column on the right shows results for all the negative news items. 0 is the day on which the news was published. 
In the case of both SRI stocks and non-SRI stocks the test was run for the entire sample and also distinguished between events that may be considered either positive or negative from a CSR perspective. The empirical results support that the positive (negative) news items do not affect the market by creating positive (negative) abnormal returns, and the SRI stock will have not higher abnormal returns on the arrival of CSR news to the market than will non-SRI stock.

This result remains the same after splitting for positive and negative events and regardless of whether stocks were SRI or non-SRI. This seems to imply that news on sustainability and CSR does not influence the stock price of these companies. Our results differ from those obtained in previous event studies for the Spanish market. However, these studies are not directly comparable with the present study, as they focus not on the whole set of CSR news items, but exclusively on one specific type (such as environment, community, corporate and governance). The time period analysed also differs.

\subsection{Calendar-time portfolio approach}

Tables 7 and 8 present the results and performance of both the SRI and non-SRI portfolios. Panel A shows the mean, the standard deviation of excess returns and the Sharpe index in SRI portfolios, in the Ibex 35 and in an equally weighted portfolio as a control portfolio which invests in the stocks analysed. Both the Ibex 35 and the control portfolio are taken as benchmarks.

Table 7 Performance of strategies based on SRI stocks

\begin{tabular}{|c|c|c|c|}
\hline Panel A & Mean* & $S D^{*}$ & Sharpe index* \\
\hline SRI portfolio with short positions restr. & 0.0157 & 1.4663 & 1.0722 \\
\hline SRI portfolio without short positions restr. & 0.0517 & 1.9717 & 2.6206 \\
\hline Ibex 35 & -0.0155 & 1.7179 & -0.9036 \\
\hline SRI control portfolio & 0.0223 & 1.4456 & 1.5447 \\
\hline Panel B & $\alpha_{p}^{*}$ & $\beta_{p m}$ & $\operatorname{Adj} . R^{2 *}$ \\
\hline SRI portfolio with short positions restr. & $0.0081(0.6997)$ & $0.7215(0.0000)$ & 69.01 \\
\hline SRI portfolio without short positions restr. & $0.0166(0.5799)$ & $0.7421(0.0000)$ & 29.96 \\
\hline SRI control portfolio & $0.0172(0.3742)$ & $0.7083(0.0000)$ & 71.77 \\
\hline Panel C & $\alpha_{p}^{*}$ & $\beta_{p \text { control portfolio }}$ & Adj. $R^{2 *}$ \\
\hline SRI portfolio with short positions restr. & $-0.0057(0.3889)$ & $0.9943(0.0000)$ & 91.60 \\
\hline SRI portfolio without short positions restr. & $0.0217(0.2323)$ & $0.9994(0.0000)$ & 45.27 \\
\hline \multicolumn{4}{|l|}{ Panel D } \\
\hline \multicolumn{3}{|l|}{ Null hypothesis (differences equal to zero) } & $p$-value \\
\hline \multicolumn{4}{|c|}{ For the SRI portfolio with short positions restrictions: } \\
\hline \multicolumn{3}{|l|}{ Portfolio mean - portfolios simulated mean } & 0.3868 \\
\hline \multicolumn{3}{|c|}{ Portfolio Sharpe index - portfolios simulated Sharpe index } & 0.3706 \\
\hline \multicolumn{3}{|c|}{$\begin{array}{l}\text { Portfolio Jensen alpha - portfolios simulated Jensen alpha (as Panel B regression - } \\
\text { Ibex } 35 \text { as benchmark) }\end{array}$} & 0.3955 \\
\hline
\end{tabular}


Table 7 Performance of strategies based on SRI stocks (continued)

Panel D

Null hypothesis (differences equal to zero)

$p$-value

Portfolio Jensen alpha - portfolios simulated Jensen alpha (as Panel C regression -

0.3740

SRI control portfolio as benchmark)

Null hypothesis (differences equal to zero)

$p$-value

For the SRI portfolio without short positions restrictions:

Portfolio mean - portfolios simulated mean

0.3868

Portfolio Sharpe index - portfolios simulated Sharpe index

0.1751

Portfolio Jensen alpha - portfolios simulated Jensen alpha (as Panel B regression -

0.1565

Ibex 35 as benchmark)

Portfolio Jensen alpha - portfolios simulated Jensen alpha (as Panel C regression SRI control portfolio as benchmark)

Note: data refer to a sub-sample of 75 CSR-related news items about seven SRI companies listed in the Spanish stock exchange over the period October 1997December 2002 from the Baratz press database.

Table 8 Performance of strategies based on non-SRI stocks

\begin{tabular}{|c|c|c|c|}
\hline Panel $A$ & Mean* & $\begin{array}{l}\text { Standard } \\
\text { deviation* }\end{array}$ & Sharpe index* \\
\hline Non-SRI portfolio with short positions restr. & 0.0284 & 2.1430 & 1.3232 \\
\hline $\begin{array}{l}\text { Non-SRI portfolio without short positions } \\
\text { restr. }\end{array}$ & 0.0377 & 1.2575 & 2.9986 \\
\hline Ibex 35 & -0.0155 & 1.7179 & -0.9036 \\
\hline Non-SRI control portfolio & 0.0396 & 1.2384 & 3.1956 \\
\hline Panel B & $\alpha_{p}^{*}$ & $\beta_{p m}$ & $\operatorname{Adj} . R^{2 *}$ \\
\hline Non-SRI portfolio with short positions restr. & $0.0357(0.5128)$ & $0.4744(0.0000)$ & 14.46 \\
\hline $\begin{array}{l}\text { Non-SRI portfolio without short positions } \\
\text { restr. }\end{array}$ & $0.0459(0.0576)$ & $0.5243(0.0000)$ & 51.30 \\
\hline Non-SRI control portfolio & $0.0478(0.0383)$ & $0.5303(0.0000)$ & 54.13 \\
\hline Panel C & $\alpha_{p}^{*}$ & $\beta_{p \text { control portfolio }}$ & $\operatorname{Adj} . R^{2 *}$ \\
\hline Non-SRI portfolio with short positions restr. & $-0.0081(0.8716)$ & $0.9206(0.0000)$ & 28.30 \\
\hline $\begin{array}{l}\text { Non-SRI portfolio without short positions } \\
\text { restr. }\end{array}$ & $-0.0016(0.8300)$ & $0.9925(0.0000)$ & 95.53 \\
\hline \multicolumn{4}{|l|}{ Panel D } \\
\hline \multicolumn{3}{|l|}{ Null hypothesis (differences equal to zero) } & $p$-value \\
\hline \multicolumn{4}{|c|}{ For the non-SRI portfolio with short positions restrictions: } \\
\hline \multicolumn{3}{|l|}{ Portfolio mean - portfolios simulated mean } & 0.6044 \\
\hline \multicolumn{3}{|c|}{ Portfolio Sharpe index - portfolios simulated Sharpe index } & 0.6013 \\
\hline
\end{tabular}


Table 8 Performance of strategies based on non-SRI stocks (continued)

\begin{tabular}{lc}
\hline Panel D & \\
Null hypothesis (differences equal to zero) & $p$-value \\
Portfolio Jensen alpha - portfolios simulated Jensen alpha & 0.6138 \\
(as Panel B regression - Ibex 35 as benchmark) & \\
Portfolio Jensen alpha - portfolios simulated Jensen alpha & 0.7815 \\
(as Panel C regression - non-SRI control portfolio as benchmark) & \\
$\begin{array}{l}\text { Null hypothesis (differences equal to zero) } \\
\text { For the non-SRI portfolio without short positions restrictions: }\end{array}$ & \\
$\begin{array}{l}\text { Portfolio mean - portfolios simulated mean } \\
\text { Portfolio Sharpe index - portfolios simulated Sharpe index }\end{array}$ & 0.5530 \\
$\begin{array}{l}\text { Portfolio Jensen alpha - portfolios simulated Jensen alpha (as Panel B regression - } \\
\text { Ibex } 35 \text { as benchmark) }\end{array}$ & 0.4442 \\
$\begin{array}{l}\text { Portfolio Jensen alpha - portfolios simulated Jensen alpha (as Panel C regression - } \\
\text { non-SRI control portfolio as benchmark) }\end{array}$ & 0.5657 \\
\hline
\end{tabular}

Note: data refer to a sub-sample of 81 CSR-related news items about five non-SRI companies listed in the Spanish stock exchange over the period October 1997December 2002 from the Baratz press database.

Performance of the two portfolios, with or without short positions restrictions. Three benchmarks are used:

1 The Ibex 35 index as proxy of the Spanish market.

2 A control portfolio that invests passively in SRI stocks.

3 A set of simulated portfolios that invests in SRI stocks following an active management strategy randomly based on the same CSR news.

The coefficients marked with $(*)$ are presented by multiplying by 100 .

Performance of the two portfolios, with or without short positions restrictions. Three benchmarks are used:

1 The Ibex 35 index as proxy of the Spanish market.

2 A control portfolio that invests passively in non-SRI stocks.

3 A set of simulated portfolios that invests in non-SRI stocks following an active management strategy randomly based on the same CSR news.

The coefficients marked with $(*)$ are presented by multiplying by 100 .

As Panel A shows, the SRI portfolio that allows short positions has the highest mean, a $0.0517 \%$ daily return in excess of the risk-free asset, which is a higher return than that obtained by investing in the Ibex 35 or in the control portfolio. After adjustment to total risk, the same result was obtained; the Sharpe index for this portfolio is thus higher than those obtained in the others. From this result, the portfolio that allows short positions can be interpreted as having a positive performance. However, this result lacks statistical significance. Panel B provides the results from model (3) using the excess return of Ibex $35, r_{m t}$ as a benchmark $\left(r_{B t}\right)$. The results in Panel B indicate the performance is not different from zero, as the constants that measure it are not significant in either of the 
portfolios. If we examine the results for the control portfolio, we can see that $\alpha$ is not significant either, which led us to repeat the analysis using the control portfolio as the benchmark. In this way, as explained above, errors due to the omission of relevant benchmarks are avoided.

Panel C shows the results of model (3) when the benchmark is the control portfolio. This analysis proved more robust than the previous one, since, from the point of view of the performance literature, it compares with the closest benchmark and only evaluates the differences associated to active management motivated by sustainability and CSR-related news. We cannot define it as a positive performance because $\alpha$ is not significant, as in the case of the SRI portfolios.

As we pointed out in the methodology section, the performance of the SRI portfolios is also benchmarked to a set of 10,000 randomly simulated portfolios. Panel D in Table 7 shows the results. At standard levels of significance, none of the null hypotheses is rejected, from which we can conclude that the performance of the portfolio is not different from what might have been achieved by its respective simulated portfolios, i.e. with active management that randomly modifies the stock weights.

These outcomes seem to imply that active management strategies based on information from sustainability and CSR news do not give significantly different results and performance from those obtained by passive management. As these strategies use the returns on the stocks analysed, it can therefore be inferred that anomalous returns associated with the effect of CSR news do not exist with sufficient economic relevance to warrant their being taken into account.

The results from the non-SRI portfolios are shown in Table 8. Panel A reports the good performance, with respect to the Ibex 35 , of the non-SRI stocks when they are aggregated in the equally weighted control portfolio, which was not the case with the SRI control portfolio. In Panel A the Sharpe ratios for these portfolios are lower than for the control portfolio. This is the first evidence that shows how an active investment strategy based on CSR news does not beat a simple and passive strategy than invests in the same stocks. Panel C confirms this result; when the control portfolio is the benchmark the coefficient $\alpha$ of the non-SRI portfolios show negative signs, but they are not significant.

Finally, we also analyse the performance of the non-SRI portfolios against a set of 10,000 simulated portfolios that follow investment strategies in the same stocks and are based on the same news contents but with random dates. If the sustainability and CSRrelated news affects the market price, the performance of both portfolios will be higher than that achieved by the random portfolios. Then, it would be expected that the $p$-value of the non-SRI portfolios that beat the random portfolios would usually be lower than $5 \%$. However, the $p$-values achieved are higher in Panel D of Table 8. Therefore, in no case is significant evidence found that CSR-related news on non-SRI stocks affects prices in the Spanish market.

\section{Conclusions}

The aim of this study was to evaluate whether the information contained in sustainability and CSR-related news in the Spanish market can be exploited economically. The empirical study distinguishes between companies that belong to an SRI index and those that do not. Information is taken from the Baratz database, which gathers financial news from the main national daily newspapers. The classifications established by the most 
important international sustainability and CSR entities were used to identify sustainability and CSR-related news items.

The Corrado non-parametric event study rank test was used to analyse the existence of significant CAR around the date of news publication; as a further step, we proposed the alternative calendar-time portfolio approach that allowed us to measure the performance achieved by active management of portfolios following trading rules related to these news items.

The results obtained with the event study methodology are coincident for both SRI and non-SRI companies. They seem to indicate that Spanish investors did not react to CSR-related news items reported in the national press during the period analysed in our study.

In order to test whether this sustainability and CSR news improved performance, the calendar-time portfolio approach was proposed. The empirical study indicates that, from an economic point of view, the results of active management based on information from CSR-related news are no better than those obtained by a passive management strategy, regardless of whether the company belongs to an SRI index or not. Despite being aware that in any analysis of the actively managed portfolio, the extent to which the result is a consequence of the specific factors of the companies that comprise the portfolio is not clearly differentiated, or on the contrary, it is influenced by the trading rules inherent to the portfolio, in our study the result can be seen both in portfolios with and without short positions. This demonstrates the robustness of the analysis in the cases of changes in the trading rules, which leads us to believe that the effect of the rules does not invalidate our conclusions.

Thus, to turn back to the question raised at the beginning of this paper, from the methodology proposed and the analysis of this sample it seems that in the short run investors do not react to sustainability and CSR-related news in the Spanish market. This lack of reaction may be due to investors' considering that the facts reported in the sustainability and CSR-related news items will not affect the company's profit and loss account. This result suggests that the model of Freeman (1984) cannot be used to explain the behaviour of Spanish investors. They act in accordance with the classical model of Friedman (1970).

It is, however, important to highlight that our results can only be applied to short-term investment strategies and in no case may be taken to indicate that socially responsible behaviour does not have beneficial effects, for example, on the company's image and reputation, which may have a greater influence on this return in the long term. This would explain why some companies follow strategies designed to make them candidates for inclusion in SRI stock indexes.

\section{Acknowledgements}

The authors thank the financial support from the Spanish Ministry of Science and Technology (SEC2003-07899), Generalitat Valenciana (research project GV04A-708) and the Universitat Jaume I (research project P1.1B2006-16). We have also benefited from comments of participants at the 2005 AEFIN Conference. 


\section{References}

Aldama (2003) Informe de la comisión especial para el fomento de la transparencia y seguridad en los mercados y en las sociedades cotizadas. Informe Aldama.

Barnett, M. and Salomon, R. (2006) 'Beyond dichotomy: the curvilinear relationship between social responsibility and financial performance', Strategic Management Journal, Vol. 27, pp.1101-1122.

Bauer, R., Derwall, J. and Otten, R. (2007) 'The ethical mutual fund performance debate: new evidence from Canada', Journal of Business Ethics, Vol. 70, pp.111-124.

Campbell, C. and Wasley, C (1993) 'Measuring security price performance using daily Nasdaq returns', Journal of Financial Economics, Vol. 33, pp.73-92.

Carroll, A.B. (1979) 'A three-dimensional conceptual model of corporate performance', Academy of Management Review Vol. 4, No. 4, pp.497-505.

Corrado, C. (1989) 'A nonparametric test for abnormal security performance in event studies', Journal of Financial Economics, Vol. 23, pp.385-395.

Deloitte and Esade. (2004) Informe de situación de la RSE en España. www.esade.es.

Diltz, D. (1995) 'Does social screening affect portfolio performance?', The Journal of Investing, Vol. 4, pp.64-69.

Drucker, P. (1984) 'The new meaning of corporate social responsibility', California Management Review, Vol. 26, pp.53-63.

Elton, E., Gruber, M., Das, J. and Hlavka, M. (1993) 'Efficiency with costly information: a reinterpretation of evidence for managed portfolios', Review of Financial Studies, Vol. 6, pp.1-22.

Fama, E., Fisher, L., Jensen, M. and Roll, R. (1969) 'The adjustment of stock prices to new information', International Economic Review, Vol. 10, pp.1-21.

Fernández-Izquierdo, M.A. and Matallín-Sáez, J.C. (2007) 'Performance of ethical mutual funds in Spain: sacrifice or premium?', Journal of Business Ethics, forthcoming.

Freeman, R. (1984) Strategic Management: A Stakeholder Approach. Marshfield, MA: Pitman Publishing Inc.

Friedman, M. (1970) 'The social responsibility of business is to increase its profits', New York, NY, Times Magazine, Vol. 32-33, 13 September, pp.122, 126.

Guerard, J. (1997) 'Is there a cost to being socially responsible in investing', Journal of forecasting, Vol. 16, pp.31-36.

Hill, R., Stephens, D. and Smith, I. (2003) 'Corporate social responsibility: an examination of individual firm behaviour', Business and Society Review, Vol. 108, pp.339-362.

Jensen, M. (1968) 'The performance of mutual funds in the period 1945-1964', Journal of Finance, Vol. 23, pp.389-415.

Kreander, N., Gray, R., Power, D. and Sinclair, C. (2005) 'Evaluating the performance of ethical and non-ethical funds: a matched pair analysis', Journal of Business Finance \& Accounting, Vol. 32, pp.1465-1493.

Kurtz, L. and Dibartolomeo, D. (1996) 'Socially screened portfolios: an attribution analysis of relative performance' The Journal of Investing, Vol. 5, pp.35-41.

Lozano, J., Albareda, L. and Balaguer, M.R. (2006) 'Socially responsible investment in the Spanish financial market' Journal of Business Ethics, Vol. 69, pp.305-316.

Mahoney, L. and Roberts, R. (2002) 'Corporate social and environmental performance and their relation to financial performance and institutional ownership: empirical evidence on Canadian firms', School of Accounting University of Central Florida. Available at: http://accounting. rutgers.edu.

Margolis, J. and Walsh, J. (2001) 'Social enterprises N 19-misery loves companies: whither social initiatives by business?’ Harward Business Working Paper Series No. 01-058. 
McWilliams, A. and Siegel, D. (1997) 'Event studies in management research: theoretical and empirical issues' Academy of Management Journal, Vol. 4, pp.626-657.

McWilliams, A., Siegel, D. and Teoh, S. (1999) 'Issues in the use of event study methodology: a critical analysis of corporate social responsibility studies', Organizational Research Methods, Vol. 2, pp.340-366.

Mill, G. (2006) ' The financial Performance of a socially responsible investment over time and a possible link with social responsibility', Journal of Business Ethics, Vol. 63, pp.131-148.

Moskowitz, M. (1972) 'Choosing socially responsible stocks', Business and Society Review, Vol. 1, pp.71-75.

Muñoz-Torres, M.J., Fernández-izquierdo, M.A. and Balaguer, M.C. (2004) 'The social responsiblility performance of ethical and solidarity funds: an approach to the case of Spain', Business Ethics. A European Review. Vol. 13, No. 2/3, pp.200-218.

Olivencia (1998) Documento de la Comisión Especial para el estudio de un código ético de los Consejos de Administración de las sociedades: El Gobierno de las sociedades cotizadas. Informe OlivenciaPástor, L. and Stambaugh, R. (2002) 'Mutual fund performance and seemingly unrelated assets', Journal of Financial Economics, Vol. 63, pp.315-349.

Porter, M.E. and Kramer, M.R. (2002) 'The competitive advantage of corporate philanthropy', Harvard Business Review, Vol. 80, No. 12, pp.56-68.

Ruf, B., Muralidhar, K., Brown, R., Janney, J. and Paul, K. (2001). 'An empirical investigation of the relationship between change in corporate social performance and financial performance: a stakeholder theory perspective', Journal of Business Ethics, Vol. 32, pp.143-156.

Shank, T., Manullang, D. and Hill, R. (2005) 'Doing well while doing good, revisited: a study of socially responsible firms' short-term versus long-term performance', Managerial Finance, Vol. 30, pp.33-46.

Sharpe, W. (1966) 'Mutual fund performance', Journal of Business, Vol. 39, pp.119-138.

Sharpe, W. (1992) 'Asset allocation: management style and performance measurement', Journal of Portfolio Management, Vol. 18, pp.7-19.

Simpson, W. and Kohers, T. (2002) 'The link between corporate social and financial performance: evidence from the banking industry', Journal of Business Ethics, Vol. 35, pp.97-109.

Statman, M. (2000) 'Socially responsible mutual funds', Financial Analysts Journal, May/June, pp.30-39.

Stone, B., Guerard, J., Gultekin, M. and Adams, G. (2001) 'Socially responsible investment screening: strong evidence of no significant cost for actively managed portfolios', Honourable Mention, Social Investment Forum Moskowitz Price.

Tsoutsoura, M. (2004). 'Corporate social responsibility and financial performance', Working Paper Series No. 7. Center for Responsible Business.

Vermeir, W. and Corten, F. (2001) 'Sustainable investment: the complex relationship between sustainability and return', Bank-en Financiewezen/Revue bancaire et financière.

Waddock, S.A. and Graves, S.B. (1997) 'The corporate social performance-financial performance link', Strategic Management Journal, Vol. 18, pp.303-319.

\section{Notes}

${ }^{1}$ The two banks BBVA and SCH were excluded from the sample because the Gescartera case and that surrounding the hidden accounts of Spanish banks in tax havens gave rise to such a volume of news on the banking sector that we were unable to establish a direct relation between the event and the date on which it occurred, and therefore were obliged to ignore these stocks as we considered that event methodology could not be applied in these cases.

${ }^{2}$ This statistic was also estimated for windows $(-5,+5)$ and $(-4,+4)$. The conclusions derived from the results obtained coincide with those for the periods included in the table. This information is available from the authors on request. 